\title{
Petrological and Structural Approach to Understanding the Mechanism of Formation and Development of Paleoproterozoic Calc-Alkaline Volcanic Rocks of West Africa's Craton: An Example of the Mako and Foulde Groups (Kedougou Inlier in Western Senegal)
}

\author{
Adrien Gozo1, Mahamadane Diène ${ }^{2 *}$, Dinna Pathé Diallo', Edmond Dioh ${ }^{3}$, Mamadou \\ Gueye $^{2}$, Papa Moussa Ndiaye ${ }^{1}$ \\ ${ }^{1}$ Département de Géologie, Université Cheikh Anta Diop, Dakar, Senegal \\ ${ }^{2}$ Institut des Sciences de la Terre, Université Cheikh Anta Diop, Dakar, Senegal \\ ${ }^{3}$ Institut Fondamental d'Afrique Noire (IFAN), Université Cheikh Anta Diop, Dakar, Senegal \\ Email: ${ }^{\text {mahamadane@netcourrier.com }}$
}

Received 1 June 2015; accepted 18 July 2015; published 22 July 2015

Copyright (C) 2015 by authors and Scientific Research Publishing Inc.

This work is licensed under the Creative Commons Attribution International License (CC BY). http://creativecommons.org/licenses/by/4.0/

(c) (i) Open Access

\section{Abstract}

The calc-alkaline volcanic formations in the western part of the Kedougou-Kenieba inlier crop out in three complexes: the Foulde in the North and the areas of Mako and Baniomba in the South. These complexes which either combine with the tholeiites or cut across the sedimentary formations are composed of thin veins and massive lava flows. They have many petrographic similarities and show chemical characteristics that resemble those of island-arc rocks. At the tectonic level, the D1 deformation phase preceding the formation of the basins and the transpressive tectonics including an oblique convergence may account for the structural evolution of the Mako volcanic belt. Its occurrence in different basins may be evidenced by the composition of some lithophilic components like the $\mathrm{Sr}, \mathrm{Ba}, \mathrm{U}, \mathrm{Rb}$ and the composition of clinopyroxenes enriched in $\mathrm{TiO}_{2}, \mathrm{FeO}_{\text {, }}$ $\mathrm{Na}_{2} \mathrm{O}$ in the Foulde calc-alkaline volcanic rocks that developed in a sedimentary environment.

\footnotetext{
"Corresponding author.
}

How to cite this paper: Gozo, A., Diène, M., Diallo, D.P., Dioh, E., Gueye, M. and Ndiaye, P.M. (2015) Petrological and Structural Approach to Understanding the Mechanism of Formation and Development of Paleoproterozoic Calc-Alkaline Volcanic Rocks of West Africa's Craton: An Example of the Mako and Foulde Groups (Kedougou Inlier in Western Senegal. International Journal of Geosciences, 6, 675-691. http://dx.doi.org/10.4236/ijg.2015.67055 


\section{Keywords}

\section{Volcanism, Calc-Alkaline, Kedougou-Kenieba Inlier, Tectonic Stress, Transpressive Tectonics}

\section{Introduction}

The Paleoproterozoic ( 2.0 Ga Birimian) of the West African craton is characterized by bimodal magmatism with successive tholeiitic-affinity volcanism and calc-alkaline volcanism (Bassot, [1]; Abouchami et al., [2]).

The calc-alkaline volcanic series have been identified in the entire Man rise (MR) and in the Kedougou-Kenieba inlier (KKI). They are well identified in Ghana (Sylvester and Attoh, [3]), Ivory Coast (Vidal and Alric, [4]; Pouclet et al., [5] [6]), Niger (Ama Salah et al., [7]), Burkina Faso (Zonou et al., [8]; Béziat et al., [9]), Guinea (Lahondère et al., [10]) and in Senegal (Bassot, [11]; Boher et al., [12]; Diallo, [13]; Dioh, [14]; Ndiaye et al., [15]; Pawlig et al., [16]; Ngom et al., [17]; Cissokho, [18]). They correspond to differentiated series ranging from the most comprehensive basalts to rhyolites.

The relations between the calc-alkaline series and their enclosing are varied. There are two types of deposits: 1) dykes or stocks cutting the tholeiitic series (Sylvester and Attoh, [3]; Zonou et al., [8] Béziat et al., [9], Cissokho [18]); 2) flows of interbedded calc-alkaline rocks or volcanic units within the upper Paleoproterozoic sedimentary series (Vidal and Alric, [4]; Pouclet et al., [5] [6]. Lahondère et al., [10]; Bassot [1]; Ndiaye et al., [15]; Dioh et al., [19]). In the KKI, the outcrops of calc-alkaline formations are in the two contexts mentioned above. They appear in the eastern edge of the Mako tholeiitic series where they cut tholeiitic basalts (Bassot, [1]; Ngom, [20]; Diallo, [13]; Cissokho, [18]) and within the sedimentary series of the Foulde Basin located in the NW (Dioh, [14]; Dioh et al., [19]).

This paper aims to analyze the petrographic, mineralogical, geochemical (rocks and minerals) characteristics of the calc-alkaline series in the western part of the Kédougou inlier and constrain, through a petrostructural study, the geodynamic context of their formation. To achieve this goal, three areas of the inlier have been considered: 1) the Foulde area where calc-alkaline series are interbedded in sedimentary series (Dioh, [14]; Dioh et al., [19]): 2) two sectors located on the eastern margin of the Mako Group corresponding to the area of Mako (Diallo, [13]; Ngom, [20]; Cissokho, [18]); and 3) the Baniomba area (Moussolo, [21]; Ngom et al., [17]).

\section{Methodology}

Based on the available topographical and geological maps, the field works are carried out in several areas of the Mako Group identified by Théveniaut et al. [22] as made predominantly by volcanic and volcano-sedimentary formations of an age between 2200 and 2170 Ma (Western part of the Kédougou inlier). Calc-alkaline Paleoproterozoic volcanic rocks are sampled and descripted in a petro-structural basis. Thin sections were made at the Universities of Nancy, Toulouse and Cheikh Anta Diop of Dakar. The minerals chemistry of major components in clinopyroxene and other mineral phases was conducted at the University of Nancy I and at GET (Geosciences Environment Toulouse). An electron microprobe (Camebax SX50) with a $15 \mathrm{KV}$ operating voltage and amperage of $10 \mathrm{~mA}$ for all items was used. Whole rock geochemistry (major, traces elements and REE) is conducted at the CRPG of Nancy and at ALS (Laboratory Group, Spain). The analytical methods used are X-ray fluorescence (major elements), emission spectrometry with inductive coupled plasma and neutron activation (traces elements and REE).

\section{Geological Framework}

In Senegal, the Paleoproterozoic appear in the Kedougou-Kenieba inlier (KKI) which, together with that of Kayes, represents the westernmost part of the West African Craton. The KKI is disconformably covered by the Neoproterozoic and Paleozoic geological formations of the Mali and Segou Madina Kouta series in the South, the Faleme (in the West) and the formations of the Taoudeni Basin in the East and North (Bassot, [1]; Theveniaut et al., [22]).

The Paleoproterozoic formations of the KKI are divided into two main lithostratigraphic units (Bassot and Dommanget [23]; Bassot, [11]; Theveniaut et al., [22]): the predominantly basic volcanoplutonic Mako Group in the Western outcrops, and in the East, the Diale-Dalema Group which is mainly sedimentary and volcano- se- 
dimentary (Figure 1). In the Northwest part of the inlier, Dioh [14] has identified another group, the volcanosedimentary Foulde Group that is equivalent to the Diale-Dalema Group.

The Mako Group consists of basalts with a wide-range of textures (pillowed or massive lavas). Ngom [20] described a first typical N-MORB basalts, and E-MORB patterns classified in a second type of basalts. Tholeiitic basalts show T-MORB characteristics in the Northern part of the Mako Group (Dioh, [24]; Diallo, [13] [25]).

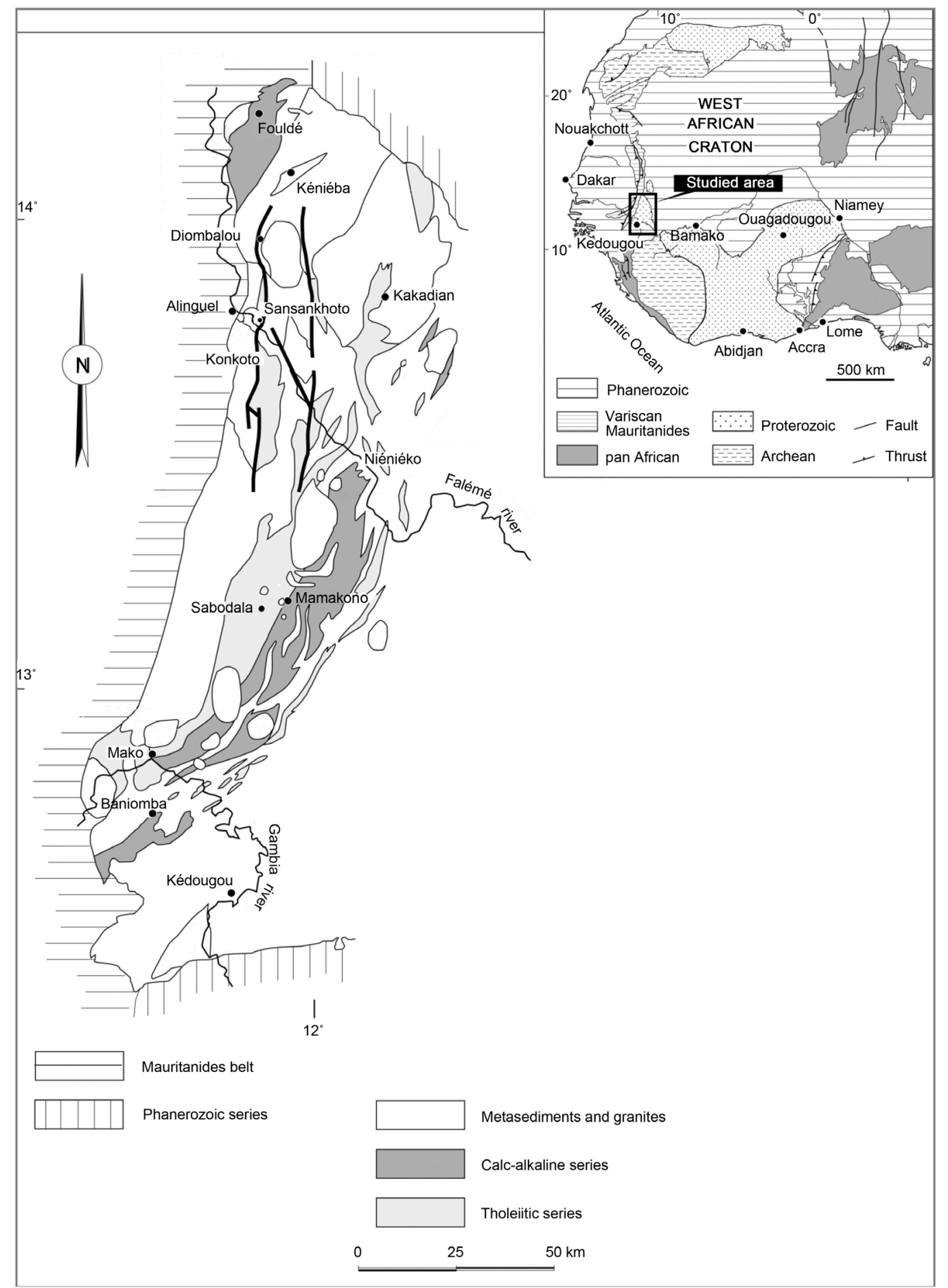

Figure 1. Position of calc-alkaline volcanic complexes in Mako and Foulde Groups (Kedougou-Kenieba inlier, eastern Senegal). 
An island arc environnement was also proposed for the Paleoproterozoic volcanic formations of the inlier (Diallo, [13] [25], Ngom [20], Pawlig et al., [16]), whereas Abouchami et al. [2] and Boher et al. [12] believed that these formations were developed in an oceanic plateau geodynamical environment.

The sedimentary and volcano-sedimentary formations of the Diale-Dalema Group in the East of the KKI are mainly carbonate rocks, shales, pelites, sandstones, arkoses, greywackes, conglomerates and tuffs. They are cutted by an intermediate calc-alkaline volcanism (Bassot, [1]; Bassot [11]; Ndiaye, [26]; Boher et al., [12]) dated around 2081 Ma (Calvez et al [27]; Hirdes et al., [28]; Gueye et al., [29]; Pawlig et al., [16]; Théveniaut et al. [22]). The Foulde Group formations in the Northwest of the Mako Group are mainly detritic (Dioh, [14]).

All the volcanic, volcano-sedimentary and sedimentary formations are affected by regional greenschist-facies metamorphism and are cut by magmatic units comprising various calc-alkaline plutonic rocks (Bassot, [1]; Dioh et al., [30]; Gueye et al., [29]) whose ages range from 2158 (Dia et al, [31], Hirdes and Davis, [28]) to 2050 Ma (Théveniaut et al., [22]).

\section{Petrography of the Mako Group Calc-Alkaline Volcanic Rocks}

In the western part of the KKI, calc-alkaline Paleoproterozoic volcanic rocks appear in the East of the Mako tholeiitic series which consist of a North-south-oriented land strip. In this strip, the calc-alkaline rocks have been studied in two areas that stretch from the North to the South: the Mako area (Diallo, [13]; Ngom, [20]; Cissokho [18]) and the Baniomba area (Moussolo, [21]; Ngom et al., [17]). The calc-alkaline rocks also crop out in the Foulde Basin in the northwestern end of the inlier (Dioh, [14]; Dioh et al., [19] [30]).

In Mako and Baniomba, these rocks show subvertical structures and form veins cutting across the tholeiitic formations and also tectonically interlayerings in the tholeiitic basalts, whereas in the Foulde area, the calc-alkaline rocks are flow-shaped (from basic to intermediate) interbedded in sediments, and specifically highly differentiated units of these units cut across sediments.

In all three areas, calc-alkaline rocks are affected by greenschist-facies Eburnean metamorphism and sometimes by a hydrothermal alteration that often makes difficult to identify primary minerals. Therefore, the identification of petrographic types will be carried out also through the chemical analyses reported on the TAS diagram $\left(\mathrm{SiO}_{2} / \mathrm{Na}_{2} \mathrm{O}+\mathrm{K}_{2} \mathrm{O}\right)$. This diagram shows that the calc-alkaline rocks indicate a differentiated serie with basalts, andesites, dacites and rhyolites. This serie is well represented in all complexes (Foulde, Mako and Baniomba). In addition, the formations appear less altered in the Mako complex than in other areas.

The studied rocks show the same petrographic characteristics whatever the areas. We shall describe the main following types: basalts, andesites, dacites and rhyolites.

Basalts with greenish colour have a microlitic and porphyritic texture including clinopyroxene phenocrysts (about $0.7 \times 1.3 \mathrm{~mm}$ ) and rarely plagioclase. The clinopyroxenes (about $30 \%$ of the rock) range from hedral to subhedral, frequently zoned and sometimes twinned, partially altered and even sometimes completely turned into amphibole. The plagioclase (An70), between $5 \%$ and $10 \%$ of the rock, with is in some rare cases phenocrysts, essentially consists of microlites. Opaque minerals are either included or not in the different mineral phases. Epidote, chlorite, calcite and quartz compose the secondary paragenesis related to metamorphism. Basalts are less voluminous than other facies.

Andesites are the most common rocks in the volcanic complexes. On outcrops, they form metric-sized bodies affected or not by the deformation.

The rocks are dark-coloured or greenish and have a porphyritic microlitic texture with a primary paragenesis mainly containing phenocrysts of pyroxene and rarely plagioclase.

Pyroxene phenocrysts (about 20\% of the rock mass) are either euhedral or subhedral and they exclusively contain clinopyroxenes that can sometimes be altered into actinolite.

Plagioclases (An37-56), in most cases are epidotised and without evidence of twinning due to the high alteration level. Secondary minerals are similar to those found in basalts.

Depending on the relative proportions of the two main mineral components, andesites form two sub-facies. The first one, rich in plagioclase (plagioclasites) is found in the Foulde complex only, and the other sub-facies represented by ferromagnesian andesites appear in every complex.

Dacites: These rocks are light coloured and show macroscopically plagioclase and ferromagnesian minerals phenocrysts of different sizes which are coated in a clear aphyric paste. A microscope examination reveals that the original texture of the rock has completely disappeared. It is replaced by secondary texture of the microgra- 
nular porphyry-type. The rock contains completely altered plagioclase $(20 \%-30 \%)$, amphibole $(10 \%-15 \%)$ and ancient ferromagnesian minerals that are difficult to identify. Secondary minerals including epidote, calcite, quartz and chlorite are enclosed in primary mineral sections.

Rhyodacites, which are poorly represented in the outcrops, are found in the Foulde and Baniomba complexes. The rock, whose colour goes from gray to light gray or pinkish gray, forms sills or low-power veins. In Foulde, this rock is affected by a cleavage trending $45^{\circ} \mathrm{N}$ with a dip of $65^{\circ}$ to the North-West.

The porphyric microlitic rock contains quartz phenocrysts (about 20\%) of different sizes that sometimes show corrosion gulfs, altered plagioclase (25\% - 30\%), biotite (20\% - 30\%) and a secondary paragenesis mainly composed of quartz crocrystals, epidote, calcite and chlorite.

The Rhyolites found in Foulde and Mako complexes are white-coloured (they are altered in such cases) or reddish. They show microlitic porphyric texture associated with automorphic quartz that sometimes present corroded sections or volcanic glass, plagioclase, sanidine and chloritised biotite. Secondary paragenesis consists of chlorite, epidote, calcite and opaque minerals in amoeboid masses.

Pyroclastic rocks: These rocks are andesitic and include tuffs and sometimes breccias. These variedly coloured rocks contain clast minerals (plagioclase, quartz and amphibole) and/or lithic andesitic elements.

\section{Mineralogy}

\subsection{Pyroxenes}

Pyroxene chemical compositions and structural formulas results are available in Gozo's thesis (in preparation). Clinopyroxenes (Cpx) have been only studied in the calc-alkaline volcanic rocks of the Foulde and Mako Groups. They are found in the basaltic and andesitic formations of all complexes. In some facies of the complexes examined, pyroxenes are completely altered into amphibole (actinolite), epidote and chlorite; in other facies, by contrast, altered and unaltered pyroxenes can coexist.

Clinopyroxenes correspond to augites. However, a small amount of clinopyroxenes seen in Baniomba (5\%) and a good number of those in the Mako facies (more than 50\%) have a diopsidic composition (Figure 2).

With the increase in $\mathrm{SiO}_{2}$ content, lower levels of $\mathrm{FeO}, \mathrm{TiO}_{2}$, and $\mathrm{Al}_{2} \mathrm{O}_{3}$ are generally noticed, and to a lesser extent, $\mathrm{MnO}$ and $\mathrm{Na}_{2} \mathrm{O}$. Meanwhile, $\mathrm{MgO}$ and $\mathrm{CaO}$ levels are increasing, whereas $\mathrm{Cr}_{2} \mathrm{O}_{3}$ shows no correlation.

When comparing $\mathrm{Cpx}$ in various complexes, we found out that for $\mathrm{SiO}_{2}$ equivalent contents, the Mako rock Cpx are poorer in $\mathrm{FeO}, \mathrm{TiO}_{2}$ and $\mathrm{Na}_{2} \mathrm{O}$ (Figure 3) and richer in $\mathrm{CaO}$ and $\mathrm{Cr}_{2} \mathrm{O}_{3}$.

The aboundant content of $\mathrm{SiO}_{2}(50 \%-55 \%)$ of the Cpx examined, which is compatible with a saturation of tetrahedral sites $(\mathrm{Si}+\mathrm{Al}=2)$, characterizes the subalkaline rocks clinopyroxenes. This trend is confirmed by their position in the $\mathrm{Ti}-\mathrm{Ca}+\mathrm{Na}$ diagram (Figure 4) of Letterier et al. [33]. The $\mathrm{Al}_{2} \mathrm{O}_{3}$ contents (about $2 \%$ on average) of Cpx are lower than those derivied from MORB-type magmas, and therefor are closer to those of pyroxenes from orogenic zone rocks. The low titanium, chromium and calcium contents also characterize the rocks from orogenic zones.

The Cpx compositions in volcanic rocks from Mako and Foulde Groups are discriminating and allow the distinction of rocks from the three complexes with a transition for the Baniomba Cpx whose compositions are between those of Mako and Foulde.

\subsection{Amphiboles}

Amphiboles have been studied only in the Foulde and Baniomba rocks. No amphibole was found in the Mako complex rocks. Their chemical composition and structural formulas are available in Gozo's thesis (in preparation).

Amphiboles in calc-alkaline volcanic formations are of calcic. Their $\mathrm{TiO}_{2}, \mathrm{Cr}_{2} \mathrm{O}_{3}, \mathrm{NiO}$ and $\mathrm{Na}_{2} \mathrm{O}$ contents are less than $1 \%$. In the Foulde basalts and andesites, amphiboles include actinolite and actinolitic hornblende. In the Baniomba complex andesites, amphiboles are composed of actinolite.

In the Foulde and Baniomba complexes, amphiboles are metamorphic and they originate from low-pressure metamorphism. Their crystal-chemical evolution has resulted in a decrease in the filling ratio of site A (Foulde) and in the absence of glaucophanic, edenetic, tschermakitic and richteritic substitutions.

When amphibole exists, it usually comes from the alteration of clinopyroxenes. The existence of primary amphiboles may be suspected in some facies and, should the case arise, the presence of chlorite shows that they 


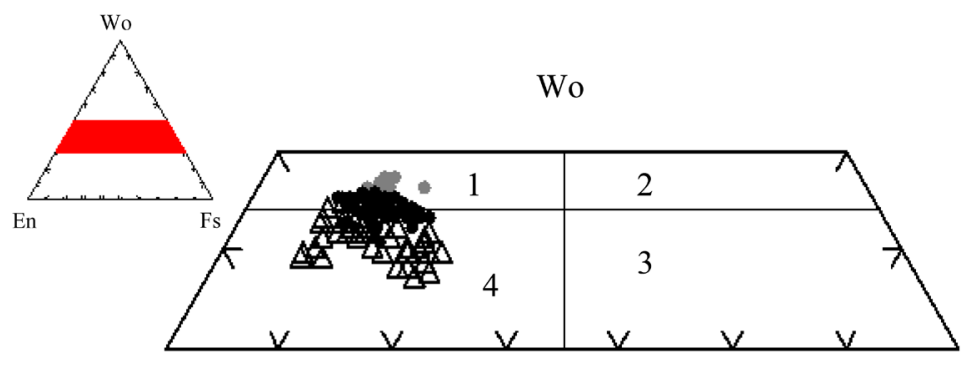

En

Wo

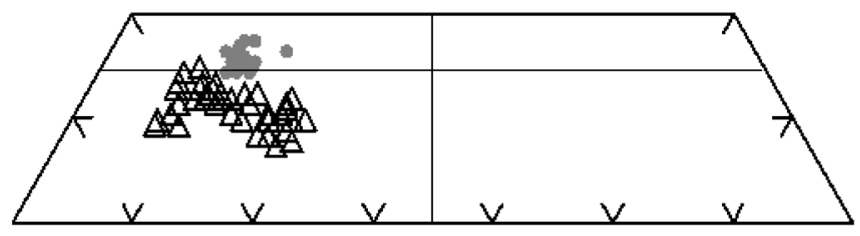

En

Fs

Wo

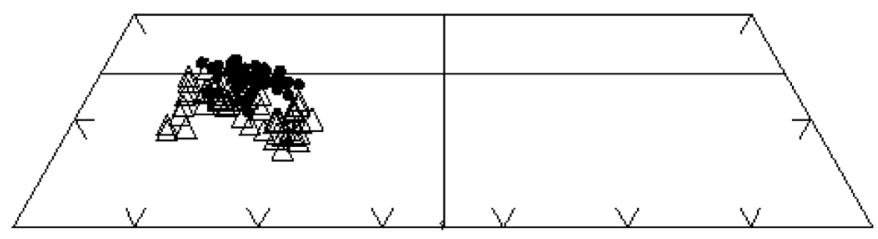

En

Fs

Figure 2. Clinopyroxene nomenclature of calc-alkaline andesites of the western part of the Kedougou inlier, in the diagram of Morimoto et al. [32]. 1: Diopside; 2: hedenbergite; 3: Augite. Triangle (Foulde); black point (Baniomba), gray point (Mako).

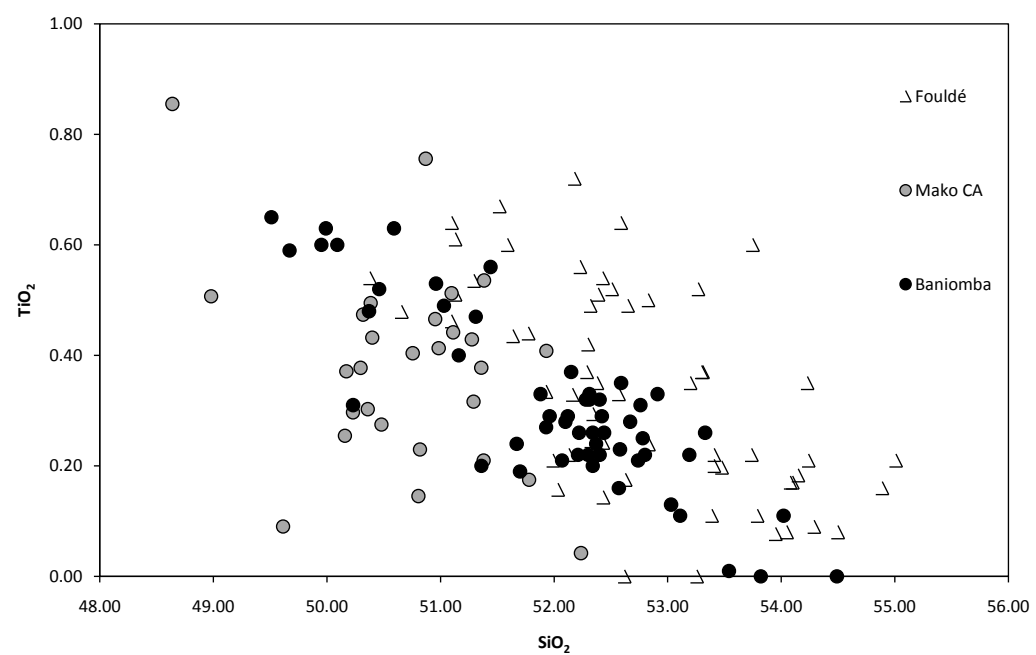

Figure 3. Main major elements variation in clinopyroxenes of calc-alkaline andesites of Mako Group as a function of $\mathrm{SiO}_{2}$. 

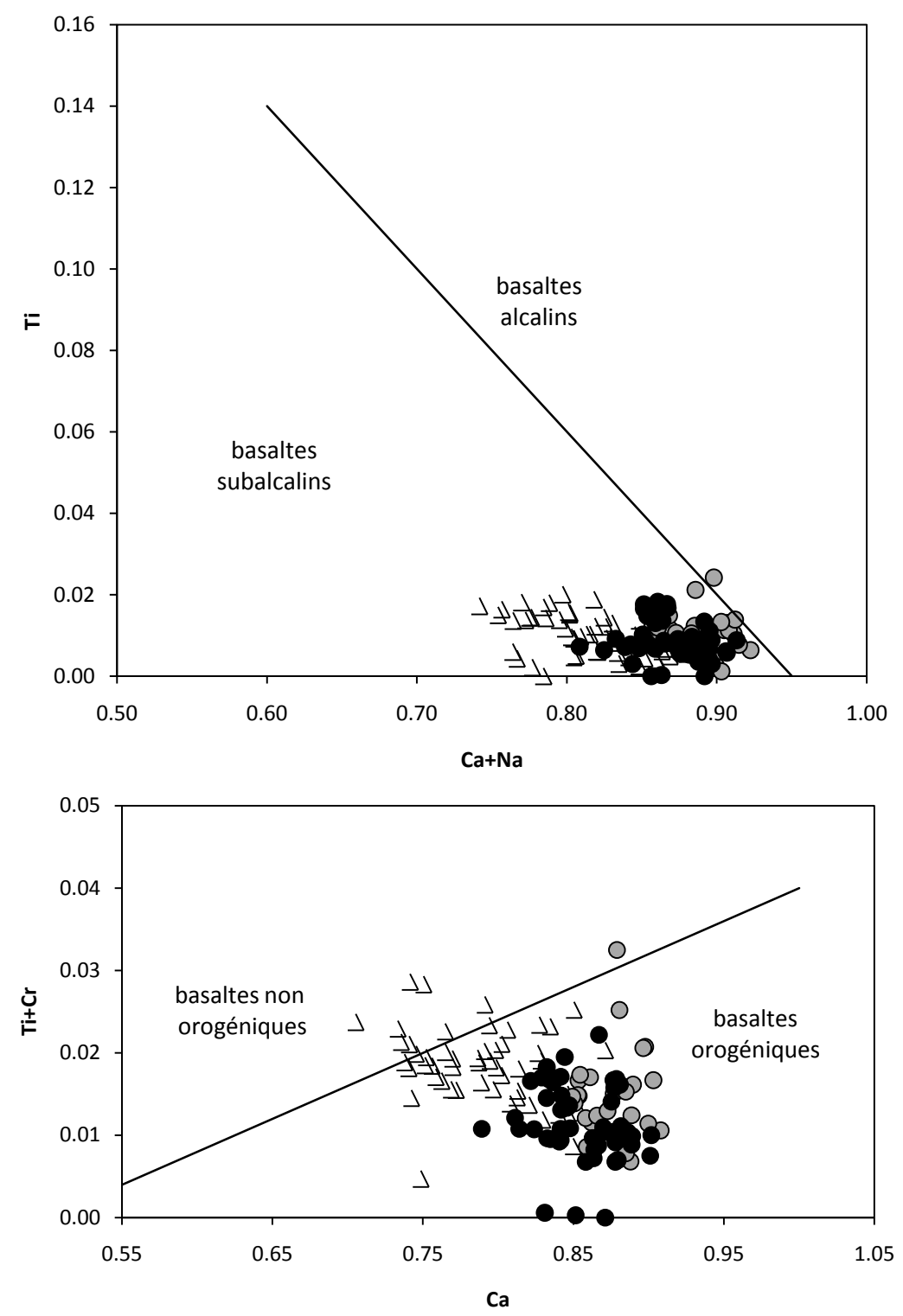

Figure 4. CPX (clinopyroxene) location in the $\mathrm{Ca}+\mathrm{Na}-\mathrm{Ti}$ diagram of Letterier et al. [33].

have started to alter.

Despite the small number of studies conducted on the amphiboles of the Baniomba complex, it seems that, like clinopyroxenes, amphiboles originating from their destabilization may be discriminating for the characterization of the different complexes.

\subsection{Plagioclases}

Plagioclases are minerals that are found in all the rocks from volcanic complexes. They form, together with clinopyroxenes, the primary paragenesis. Their proportions vary according to facies, but on the whole, they remain in lower ratios than clinopyroxenes, except in plagioclasites where they largely (90\%) prevail over other minerals. Plagioclase sections are altered or destabilized as epidote, calcite, sericite; they sometimes contain recrystallizations of quartz microcrystals.

In the andesites of the Foulde complex, we essentially find andesine, labrador, and albite and oligoclase are scarce. The andesites of the Baniomba complex rocks are mainly albite. The alterations that occurred in the pla- 
gioclases among which the albitisation (Ab 67\% - 99\%), must be connected to the greenschist-facies metamorphism.

\section{Whole Rock Geochemistry}

The geochemical data (Table 1) show important correlations based on silica $\left(\mathrm{SiO}_{2}\right)$, despite its well-known

Table 1. Chemical analyzes of Foulde; Mako and Baniomba complexes.

\begin{tabular}{|c|c|c|c|c|c|c|c|c|c|}
\hline & \multicolumn{3}{|c|}{ Foulde } & \multicolumn{3}{|c|}{ Mako } & \multicolumn{3}{|c|}{ Baniomba } \\
\hline & $\begin{array}{l}\text { basaltes } \\
\text { M4 }\end{array}$ & $\begin{array}{l}\text { Andesites } \\
\text { M5 }\end{array}$ & $\begin{array}{c}\text { Rhyolites } \\
\text { M8 }\end{array}$ & $\begin{array}{c}\text { Basaltes } \\
\text { M3 }\end{array}$ & $\begin{array}{c}\text { Andesites } \\
\text { M2 }\end{array}$ & $\begin{array}{c}\text { Rhyolites } \\
\text { M2 }\end{array}$ & $\begin{array}{c}\text { Basaltes } \\
\text { M3 }\end{array}$ & $\begin{array}{c}\text { Andesites } \\
\text { M2 }\end{array}$ & $\begin{array}{c}\text { Rhyolites } \\
\text { M4 }\end{array}$ \\
\hline $\mathrm{SiO}_{2}$ & 52.94 & 57.46 & 68.72 & 50.10 & 58.12 & 72.53 & 54.52 & 55.39 & 64.59 \\
\hline $\mathrm{TiO}_{2}$ & 0.70 & 0.71 & 0.41 & 0.78 & 0.96 & 0.54 & 0.70 & 0.70 & 0.43 \\
\hline $\mathrm{Al}_{2} \mathrm{O}_{3}$ & 13.21 & 15.19 & 14.73 & 12.38 & 16.34 & 12.94 & 13.81 & 14.21 & 13.64 \\
\hline $\mathrm{Feo}^{*}$ & 10.27 & 8.40 & 3.86 & 10.24 & 8.77 & 4.56 & 9.74 & 9.08 & 4.29 \\
\hline $\mathrm{MnO}$ & 0.17 & 0.13 & 0.09 & 0.17 & 0.10 & 0.10 & 0.16 & 0.14 & 0.06 \\
\hline $\mathrm{MgO}$ & 8.88 & 5.29 & 2.21 & 9.57 & 3.36 & 0.99 & 6.64 & 5.63 & 3.76 \\
\hline $\mathrm{CaO}$ & 9.66 & 7.17 & 2.89 & 10.56 & 4.37 & 1.91 & 8.69 & 6.49 & 4.96 \\
\hline $\mathrm{Na}_{2} \mathrm{O}$ & 2.32 & 3.29 & 3.22 & 1.93 & 7.56 & 2.21 & 2.39 & 3.46 & 3.57 \\
\hline $\mathrm{K}_{2} \mathrm{O}$ & 1.24 & 2.14 & 2.77 & 1.31 & 0.27 & 2.73 & 2.37 & 2.31 & 0.70 \\
\hline $\mathrm{P}_{2} \mathrm{O}_{5}$ & 0.25 & 0.22 & 0.07 & 0.20 & 0.16 & 0.15 & 0.27 & 0.25 & 0.07 \\
\hline $\mathrm{Rb}$ & 37 & 58 & 104 & 38 & 6 & 85 & 170 & 64 & 24 \\
\hline $\mathrm{Ba}$ & 401 & 511 & 1976 & 356 & 80 & 424 & 775 & 714 & 244 \\
\hline Th & 1.69 & 2.05 & 7.588 & 0.98 & 1.05 & 4.605 & 1.36 & 1.85 & 1.5425 \\
\hline $\mathrm{U}$ & 0.74 & 0.80 & 1.68 & 0.39 & 0.40 & 0.80 & 0.61 & 0.63 & 0.55 \\
\hline $\mathrm{Nb}$ & 4.93 & 5.77 & 28.90 & 2.73 & 5.76 & 17.75 & 3.30 & 5.15 & 4.00 \\
\hline $\mathrm{Ta}$ & 0.20 & 0.30 & 1.22 & 0.17 & 0.45 & 1.30 & 0.20 & 0.35 & 0.35 \\
\hline $\mathrm{La}$ & 11.76 & 14.88 & 38.23 & 9.83 & 13.00 & 29.78 & 9.40 & 12.60 & 8.05 \\
\hline $\mathrm{Ce}$ & 26.47 & 32.24 & 82.29 & 24.07 & 28.97 & 63.28 & 21.20 & 26.25 & 16.50 \\
\hline Pr & 3.47 & 4.34 & 9.77 & 3.41 & 3.69 & 7.76 & 2.82 & 3.33 & 2.01 \\
\hline $\mathrm{Sr}$ & 517 & 506 & 337 & 409 & 166 & 104 & 576 & 349 & 348 \\
\hline $\mathrm{Nd}$ & 14.55 & 16.45 & 37.37 & 15.63 & 16.48 & 31.03 & 12.90 & 14.30 & 8.58 \\
\hline $\mathrm{Sm}$ & 3.75 & 3.66 & 7.49 & 3.76 & 3.76 & 6.45 & 3.14 & 3.39 & 2.02 \\
\hline $\mathrm{Zr}$ & 82 & 97 & 293 & 67 & 143 & 382 & 70 & 85 & 95 \\
\hline Hf & 2.10 & 2.50 & 5.95 & 1.90 & 3.60 & 8.20 & 1.80 & 2.35 & 2.63 \\
\hline $\mathrm{Eu}$ & 1.04 & 1.03 & 0.83 & 1.07 & 1.24 & 1.49 & 0.91 & 0.99 & 0.63 \\
\hline Gd & 3.88 & 3.60 & 6.50 & 3.56 & 4.13 & 6.45 & 3.05 & 3.33 & 1.97 \\
\hline $\mathrm{Tb}$ & 0.56 & 0.49 & 1.00 & 0.54 & 0.65 & 1.03 & 0.45 & 0.52 & 0.29 \\
\hline Dy & 3.04 & 2.87 & 5.87 & 3.10 & 4.23 & 6.52 & 2.68 & 3.15 & 1.61 \\
\hline $\mathrm{Y}$ & 18.53 & 16.89 & 39.15 & 17.43 & 26.48 & 40.27 & 15.10 & 17.75 & 8.80 \\
\hline Ho & 0.61 & 0.63 & 1.24 & 0.67 & 0.89 & 1.42 & 0.56 & 0.68 & 0.33 \\
\hline $\mathrm{Er}$ & 1.83 & 1.62 & 3.58 & 1.94 & 2.61 & 4.29 & 1.77 & 2.08 & 0.92 \\
\hline $\mathrm{Tm}$ & 0.24 & 0.27 & 0.51 & 0.27 & 0.38 & 0.66 & 0.23 & 0.29 & 0.13 \\
\hline $\mathrm{Yb}$ & 1.57 & 1.52 & 3.15 & 1.64 & 2.54 & 4.31 & 1.48 & 1.93 & 0.77 \\
\hline $\mathrm{Lu}$ & 0.28 & 0.26 & 0.47 & 0.26 & 0.41 & 0.71 & 0.23 & 0.31 & 0.12 \\
\hline $\mathrm{Ni}$ & 105 & 37.8 & 3.2 & 156 & & & 57 & 67 & 160.25 \\
\hline $\mathrm{Cr}$ & 666 & 203 & 9 & 740 & & & 420 & 215 & 240 \\
\hline $\mathrm{V}$ & 218 & 164 & 62 & 256 & 170 & 38 & 232 & 237 & 76 \\
\hline Co & 56 & 28 & 13 & 50 & & & 38 & 32 & 19 \\
\hline
\end{tabular}


mobility during alteration and metamorphism. Alkalis $\left(\mathrm{Na}_{2} \mathrm{O}\right.$ and $\left.\mathrm{K}_{2} \mathrm{O}\right)$, too, which are reputedly mobile during post-magmatic phenomena reveal, in the facies examined, a noticeable increase with the rise of $\mathrm{SiO}_{2}$, despite the dispersion shown in the diagrams. In addition, the alkalis contents of these elements are not excessively high in the rocks, as they correspond to those found in calc-alkaline series. This observation rules out the hypothesis of an enrichment of these two oxides during the post-magmatic phenomenon. For all those reasons, we believe that these elements can be used in the discrimination diagrams.

To make a comparison between complexes, we considered the facies belonging to the same evolution stage, basing our study on the classification of Gelinas and Brooks [34]. Thus we made the distinction between basalts $\left(\mathrm{SiO}_{2} \leq 54 \%\right)$, andesites $\left(54 \%<\mathrm{SiO}_{2}<62 \%\right)$, dacites and rhyodacites $\left(62 \%<\mathrm{SiO}_{2}<71 \%\right)$, and rhyodacites $\left(\mathrm{SiO}_{2} \geq 71 \%\right)$.

\subsection{Major Elements}

The major elements data show a significant variation in the silica contents $(50 \%$ to $78 \%)$ of the rocks from Foulde and Baniomba complexes. They also reveal $\mathrm{TiO}_{2}, \mathrm{MnO}$ and $\mathrm{P}_{2} \mathrm{O}_{5}$ almost invariably low contents (below $1 \%)$ in the rocks from all complexes; these contents decrease with the silica increase.

The MgO levels range from $0.2 \%$ to $11.4 \%$ and show a negative correlation with $\mathrm{SiO}_{2}$.

The $\mathrm{CaO}$ trend follows the MgO evolution, with contents ranging from $0.05 \%$ to $10.4 \%$. The same phenomenon occurs for the $\mathrm{FeO}$ whose contents vary from $0.3 \%$ to $11.5 \%$. The analysis of the geochemical data of major and trace elements allows us to conclude that the contents of $\mathrm{MgO}, \mathrm{CaO}$ and $\mathrm{FeO}$ are generally high in basalts and andesites, but those contents must be related to the predominant ferromagnesian phases.

$\mathrm{Na}_{2} \mathrm{O}$ and $\mathrm{K}_{2} \mathrm{O}$ whose contents vary respectively from $1.05 \%$ to $4.3 \%$ and $0.11 \%$ to $4.21 \%$, sometimes have high acid levels; they increase during differentiation.

Referring to the major elements in the $\mathrm{Na}_{2} \mathrm{O}+\mathrm{K}_{2} \mathrm{O}-\mathrm{SiO}_{2}$ classification diagram, the rocks studied are variously or unevenly distributed depending on the type of complexes (Figue 5). Thus, the Foulde calc-alkaline rocks include basalt, andesite, dacite/rhyodacite and rhyolite. This complex is the most differentiated one because it contains various rocks ranging from basalts to rhyolites. The Baniomba rocks are basalts, basalts/andesites, andesites and dacites, and the Mako rocks include basalts or andesites and rhyolites.

The $\mathrm{Na}_{2} \mathrm{O}+\mathrm{K}_{2} \mathrm{O}-\mathrm{SiO}_{2}$ diagram shows that the rocks examined belong to the subalkaline-type. This trend is confirmed by the iron, magnesium and alkaline contents that are compatible with the evolution of calc-alkaline formations.

\subsection{Trace Elements and Rare Earths}

Geochemical data of trace elements show the following: Chromium contents vary from 10 to $1032 \mathrm{ppm}$ and show a

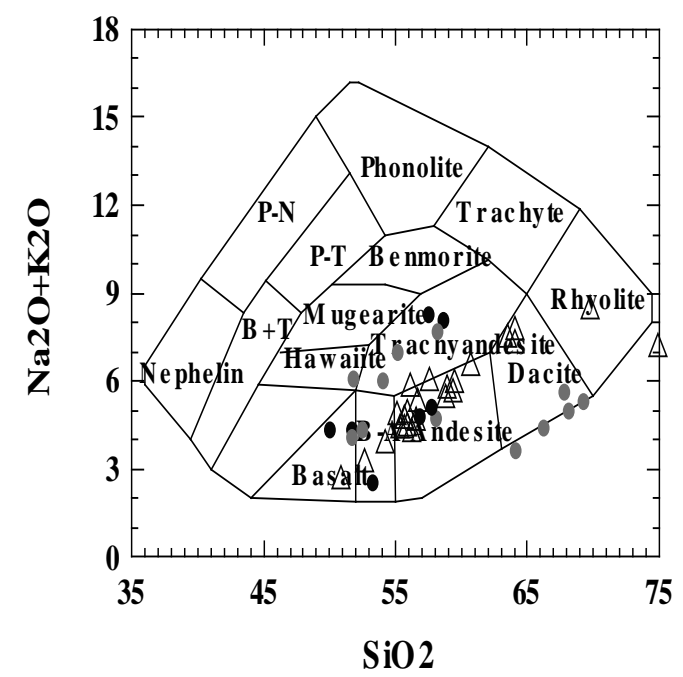

Figure 5. Calc-alkaline volcanic rocks in the $\mathrm{Na}_{2} \mathrm{O}+$ $\mathrm{K}_{2} \mathrm{O}-\mathrm{SiO}_{2}$ diagram. 
negative correlation with $\mathrm{SiO}_{2}$, and $\mathrm{Co}$ and $\mathrm{V}$ contents show the same evolution as $\mathrm{Cr}$; their contents respectively range from 0.5 to $68 \mathrm{ppm}$ and 6 - $271 \mathrm{ppm}$. Zr concentrations range from 60 - 177 ppm; and are quite high in acidic samples. They increase during differentiation.

Nickel, 96 ppm on average in basaltic rocks, shows concentrations lower than those of rocks from primary magmas that characteristically rise over 200 ppm (Sato, [35]; Hart and David, [36]).

In basalts, the extension of the spectrum of rare earth elements (REE) to other trace elements doesn't show a distinction between the three complexes. They have the same patterns (Figure 6(a)), with positive anomalies in

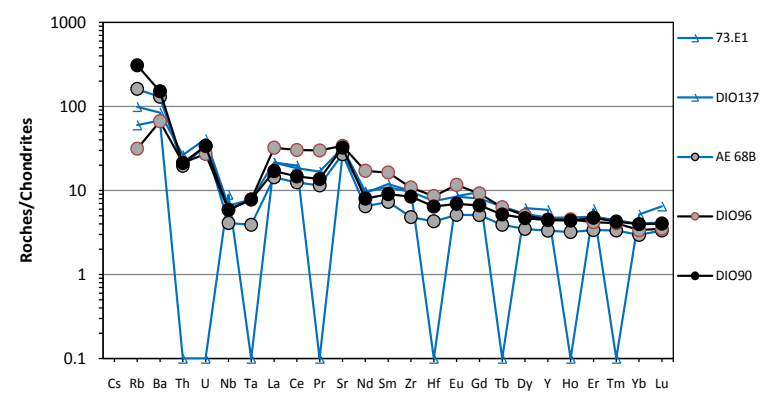

(a)

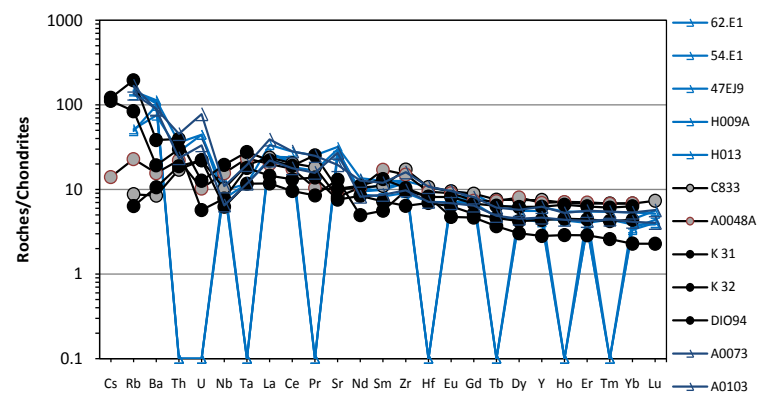

(b)

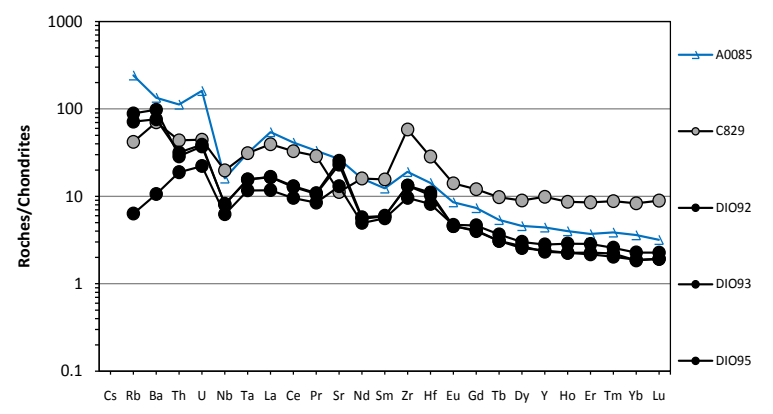

(c)

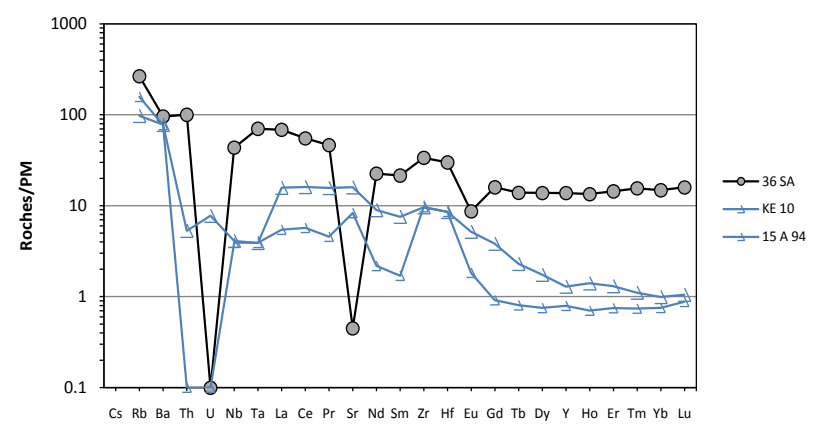

(d)

Figure 6. Widened spectra of rare earths elements of basalts (a), Andesites (b), dacites and rhyodacites (c) and rhyolites (d). 
$\mathrm{U}$, Sr and sometimes in Ba (only for Foulde formations), and negative anomalies in $\mathrm{Nb}$ and Th. The overall for rare earths is $73.23 \mathrm{ppm}$ for the Foulde basalts, $83.74 \mathrm{ppm}$ for those of Mako, and $60.82 \mathrm{ppm}$ for Baniomba basalts. The ratios $(\mathrm{La} / \mathrm{Yb})_{\mathrm{N}}$ are close to 4.15; 7.2; 4.28 respectively for the Foulde, Mako and Baniomba complexes. The ratios $(\mathrm{La} / \mathrm{Sm})_{\mathrm{N}}$ are close to $1.80 ; 1.96 ; 1.88$ respectively and $(\mathrm{Gd} / \mathrm{Yb})_{\mathrm{N}}$ have values of $1.85 ; 2.21$; 1.66 respectively for the Foulde, Mako and Baniomba basalts.

It is probably in the andesites (Figure 6(b)) that we find the most significant differences between complexes. Sr contents go from 346 to 569 ppm in Foulde, from 247 to 294 ppm in Baniomba and from 145 to 186 ppm in Mako; Ba respectively ranges from 383 to 582 ppm, 35 to 997 ppm and 43 to 117 ppm for Foulde, Bagnomba and Mako; U goes from 0.8 to $1.40 \mathrm{ppm}$ (Foulde), from 0.4 to $0.7 \mathrm{ppm}$ (Baniomba) and $0.40 \mathrm{ppm}$ (Mako); the ratios $(\mathrm{La} / \mathrm{Yb})_{\mathrm{N}}$ in Foulde range from 3.6 to 7.7, from 4.2 to 6.1 in Baniomba and 3.4 in Mako. The extension of rare and heavy earths ranging respectively from 12.94, 13.27 to 20.27 ppm in Foulde, Baniomba and Mako, establish a distinction among the three complexes.

For dacites and rhyodacites (Figure 6(c)) ratios (La/Yb) $)_{\mathrm{N}}$ are higher in Foulde (15.1) Baniomba (5.2 to 9) and Mako (4.7) formations. The total number of rare earths is $127.96 \mathrm{ppm}, 44.73 \mathrm{ppm}$ and $137.36 \mathrm{ppm}$ respectively for Mako, Baniomba and Foulde.

In Foulde and Mako, the ratio $(\mathrm{La} / \mathrm{Yb})_{\mathrm{N}}$ of rhyolites, like in the previous facies, is more pronounced $(7.2$ to 15.9) in Foulde, compared to Mako (4.6) (Figure 6(d)). The total content of REEs is $202.41 \mathrm{ppm}$ and $37.49 \mathrm{ppm}$ respectively for Mako and Foulde.

Therefore, the spidergram of REEs extended to trace elements shows that the Foulde Group formations differ from those of the Mako Group regarding elements such as the extent of heavy rare earths (HREE), and the contents in $\mathrm{Sr}, \mathrm{Ba}, \mathrm{Rb}$ that are lithophile elements. The contents in these lithophile elements, which are very high in the andesites of the Foulde Group, reveal that the sedimentary environment has played a significant role in the formation of such rock.

\section{Structural Data}

The lithostructural map of the Mako Group (Diene, [37]) resulting from the combination of the lithological and the tectonic maps shows a number of relationships, mainly geometric, between lithology and tectonics. This analysis is based on the findings from both laboratory work and fieldwork. The contacts between the different lithological formations are established through tectonic boundaries (Figure 8). The geometric design of the spatial distribution of the major lithological units (Figure 7) suggests a synchronic relationship between tectonics and magmatism. The lithostructural evolution of the Mako Group reveals great lithotectonic units, notably various basins including marginal and pull-apart basins (Diene et al., [38]).

\subsection{Intra-Block BASINS}

These basins are located between or inside greenstone panels (greenstone belts). In the Mako panel (Figure 8) the tectonic evolution has generated the development of a basin inside the panel. Tectonic structures evidenced by N-S faults, NE-SW to E-W in addition to NW-SE faults, generally form the boundaries of facies. The direction of both the motion and relationships among the various faults follows North-South sinistral displacements replaced by secondary NE-SW to E-W faults that may have brought about the development of these basins inside the greenstone panels.

\subsection{Marginal Basins}

These basins expand from the North to the South and border the Greenstone Belt (Figure 7). A tight examination of this figure reveals two types of basins: the basins bordering the greenstone panels and the basins located within the former basins. The latter basins will be called type II basins. All these basins are separated by NE-SW to N-S transcurrent tectonic structures, and they may form facies boundaries.

\section{$\checkmark$ Border basins}

They are located on the edge of greenstone panels. These basins surround greenstone belts and their limits are marked by NE-SW to N-S faults such as MTZ (Main Transcurrent Zone) and the Badon-Nienieko and LeobaMoussala shear zone systems (Diene, [37]).

These types of basin are common in deflection corridors. They represent real isoclinal folds suggesting dipeffect sedimentation, with detritic filling and heavily eroded high margins. These basins are somewhat overlapping 


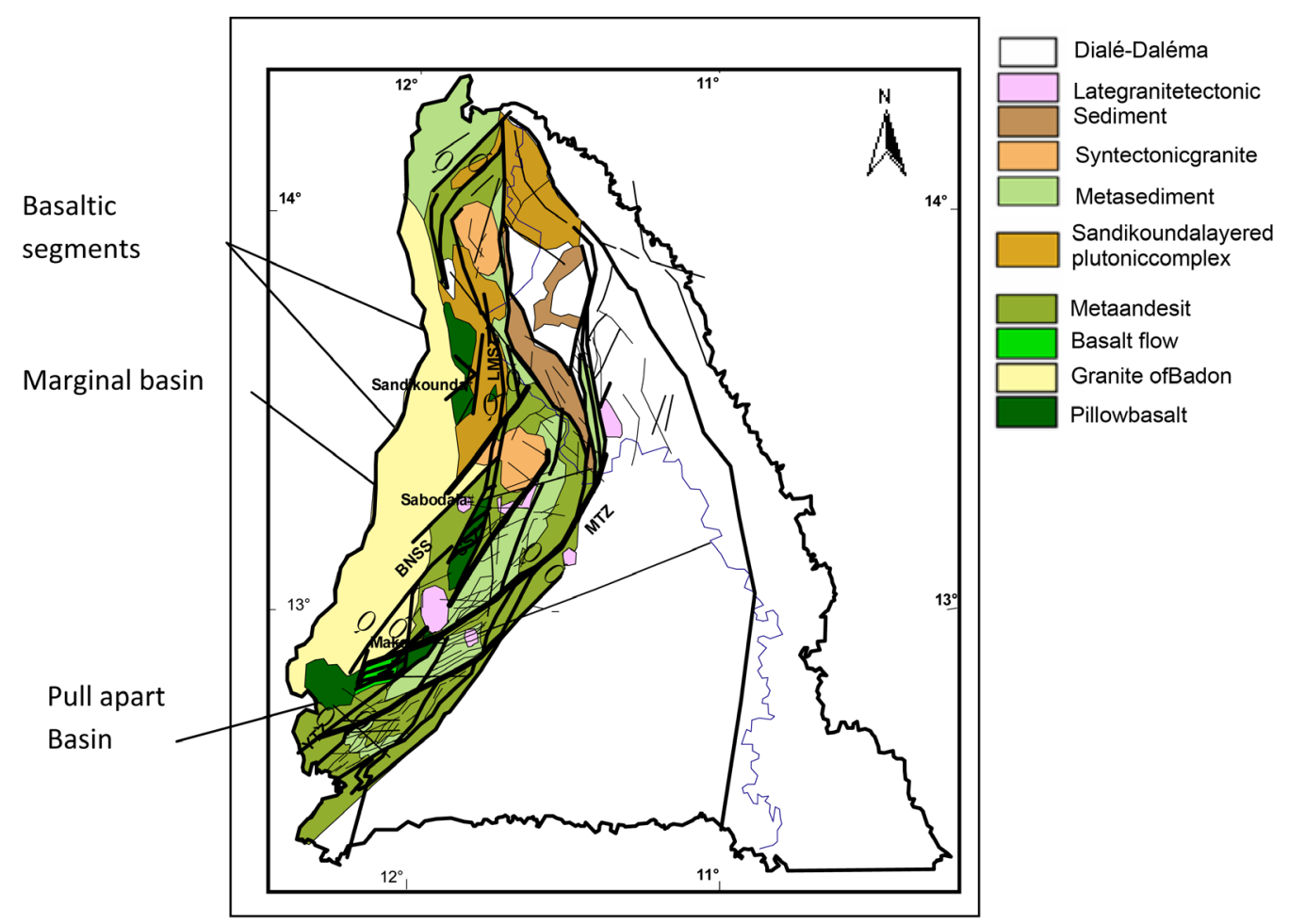

Figure 7. The main lithostructural patterns of the Mako group (Diène, [37]).

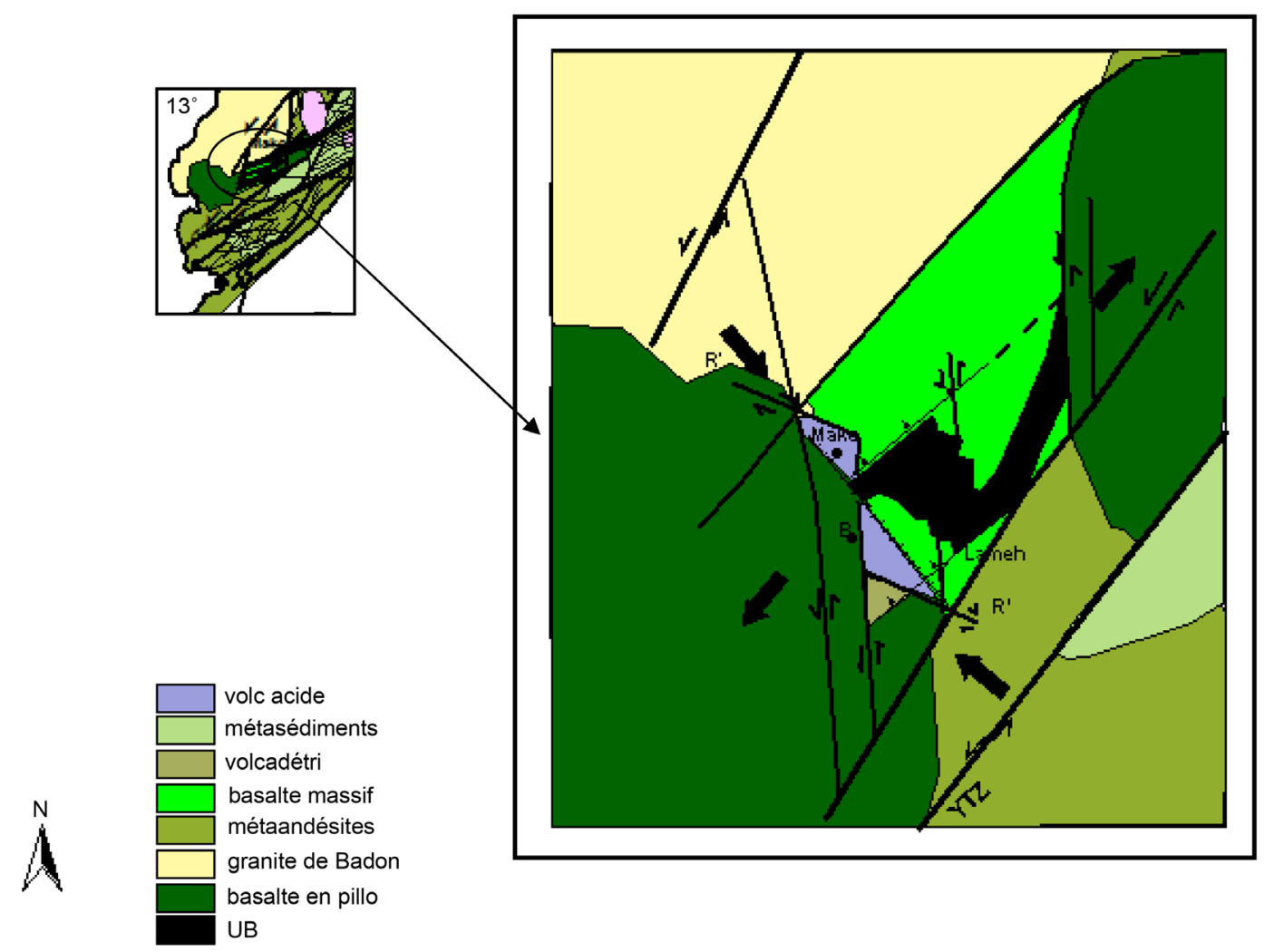

Figure 8. Setting up the intra-block basin inside the Mako panel under transpressional regime accompanied by the rise of UB (Ngom et al., [17], modified). 
and are characterized by noticeable volcanism. The process of filling these basins will be completed by the debris from the erosion of the rocks that composed the high margins of greenstone panels, and by calc-alkaline volcanism as well. Inside those basins, the intermediate volcanism is especially marked by volcanic agglomerates evidencing sub-aerial volcanism which thus forms an andesitic complex. The lithology in the basins on the edge of the Mako Group consists, in its Southern part, in andesitic conglomerates that pass eastward to the Baniomba andesites (massive lava). In the northern parts, more specifically in the Foulde Group, the andesitic sequence could be equivalent to that of the southern part (Baniomba). These rock formations constitute an andesitic complex with volcano-detritic and volcanic features.

\section{$\checkmark$ Type II basins}

They are located within the first type of basins. Their sedimentation is different from that of dip-effect basins (type I) and they are imbedded in NE-SW and NS faults. This sedimentation is mainly composed of detritic metasediments but also of andesitic tuffs and gaps. The development of these basins may be caused by the system of North-South faults surrounded by NE-SW major faults such as the MTZ. These North-South faults may be transform faults that had replaced the sinistral displacements of NE-SW accidents, thus causing the formation of openings or basins within border basins.

\subsection{Pull-Apart Basins}

The observation of the Mako Group lithostructural map (Diene, [37]) reveals the existence of basins that have evolved into pull-apart basins, notably the Tinkoto Basin and the Molassic Basin in northern Tourekhoto. Both basins have been formed along the MTZ, in the South and North, respectively. The creation and evolution of these basins occurred under tectonic control. The rotation of the NNW-SSE; NW-SE to WNW-ESE shortening stress imposes the passage from an NS sinistral transpressive regime to an NE-SW dextral transpressive regime. NE-SW major faults have caused the development of pull-apart basins including that of Tinkoto. Its filling will occur under tectonic control with coarse detritic additions made to synsedimentary calc-alkaline volcanism, but also to volcanic and detritic products. These detritic additions essentially consist of conglomeratic, grauwackian, sandstone and pelitic elements. All these formations are affected by straight folds and NE-SW shear corridors.

The structural evolution of the Mako Group is marked by two deformation phases that form a contunium: a tangential D1 phase that caused the crustal thickening and which is related to a horizontal shortening of the crust; this resulted in the formation of marginal basins; a D2-3 evolution characterized by transcurrent tectonics controlling the geometry and evolution of pull-apart basins (Diene et al., [38]). These two evolutions may create NE-SW, NS, EW and NW-SE-oriented overlapping and transcurrent structures affecting the whole aspect of the volcanic belt. The study of the sedimentation and deformation inside the basins suggests that the D2-3 transcurrent phase has caused the development of these basins. The structural evolution of the Mako volcanic belt is characterized by deformations dominated by a D1 phase preceding the formation of basins and transpressive tectonics that includes an oblique convergence (Diene et al., [38]). The sedimentation in the various basins filled with continental calc-alkaline, volcano-sedimentary and detritic volcanic rocks, together with the distortions affecting these formations, could suggest that transpressive tectonics associated with oblique subduction may have caused the development of pull-apart basins and subaerial volcanism. This structural evolution may also be marked by a progressive formation of basins starting with marginal basins and proceeding to pull-apart basins.

\section{Petrogenesis}

The high concentrations of transition elements (nickel, chromium, vanadium, cobalt) of magnesium, iron and calcium inside basaltic and andesitic rocks indicate the presence of ferromagnesian minerals. Thus, we can assume that these rocks originate from magmas resulting from the partial melting of the upper mantle, or from a richer source that contains these elements. Indeed, the rocks that compose the mantle are rich in minerals containing high concentrations of transition elements (olivine and pyroxene); the melting of such a rock can produce magmatic fluid enriched with these elements. This observation is compatible with the ratio values as $(\mathrm{La} / \mathrm{Yb})_{\mathrm{N}},(\mathrm{La} / \mathrm{Sm})_{\mathrm{N}},(\mathrm{Gd} / \mathrm{Yb})_{\mathrm{N}}$ and $\mathrm{Al}_{2} \mathrm{O}_{3} / \mathrm{TiO}_{2}$, which suggests the existence of a spinel Lherzolitic source or low-garnet source. The $(\mathrm{La} / \mathrm{Yb})$ ratios $(1.36$ to 4.12$)$ are a strong argument for the involving of the melting of a lithospheric mantle source (El Hadi et al., [39]). The La/Ta ratios (more than 26) of some rocks suggest a lithospheric mantle source contaminated by a continental crust component (Leat et al., [40]). The concentrations of $\mathrm{Ni}$ (in almost all samples) below $200 \mathrm{ppm}$ are not compatible with a direct origin from primary magmas. The 
evolving nature of magmatic liquid is also evidenced by the low values of the Mg number (between 0.16 and 0.67), which indicates that they correspond to those of evolved magmatic liquids.

Changes in silica contents and the presence of facies from basic to acid members evidence the differentiated nature of the magmas. The decrease of the concentration of some elements (nickel, chromium, cobalt, vanadium, iron, magnesium, calcium) from the least to the most differentiated rocks also shows the role played by the fractional crystallization that might be controlled by clinopyroxene and/or plagioclase fractionnation.

The origin of calc-alkaline Paleoproterozoic volcanic series from a unique magmatic source of either heterogeneous composition or not, could be considered as a defendable argument. This magma may have caused the formation of rocks developed at different times in the arc-basins, as a result of tectonic stresses.

Consequently, the magmatic source of the calc-alkaline series of Mako and Foulde complexes may be the same, but Mako's belonging to the intra-block basin and Foulde to the pull-apart basin may have generated differences in the chemistry of CPX and in some trace elements. The Baniomba formations that had been developed in a marginal basin show intermediate characteristics.

In summary, based on some parameters such as the composition of the CPX and the trace elements contents, there apparently existed an evolution among the Mako formations that cropped out next to or inside the basic volcanic rocks of tholeiite-type from the Mako Group, the Foulde formations developed in a pull-apart basin and the Baniomba complex formations whose average compositions lied between those of Mako and Foulde.

\section{The Geodynamic Context}

The low contents in $\mathrm{TiO}_{2}$ and the high contents in lithophilic elements are in accordance with a development in an orogenic context. This orogenic environment is also confirmed by the Ti/V ratios below 40 , very high $\mathrm{Ba} / \mathrm{Nb}$ (El Hadi et al., [39]), Th/U and Th/Ta (higher than 1), which are similar to those encountered in the rocks from orogenic contexts. In the discrimination diagrams proposed by Pearce and Cann [41] (Figure 9), the rocks from all complexes are developed in an island-arc environment. The ratios $\mathrm{Ce} / \mathrm{Yb}$ below 15 (2.89 to 11.46) make them closer to those of lowly-enriched island-arcs. This observation is also confirmed by the ratios $(\mathrm{La} / \mathrm{Yb})_{\mathrm{N}}$ which are generally moderate or moderately elevated.

The structural analysis indicates that contacts among lithological formations are tectonic in nature; they create intra-block basins (Mako), marginal basins on the edge of greenstones (Baniomba) and pull-apart basins (Foulde). The characteristics of their rocks are akin to each other regarding major and trace elements, but still, there exists a huge difference between the $\mathrm{Ba}, \mathrm{Sr}, \mathrm{Rb}$ contents and the $\mathrm{U}$ contents.

\section{Ti/100}

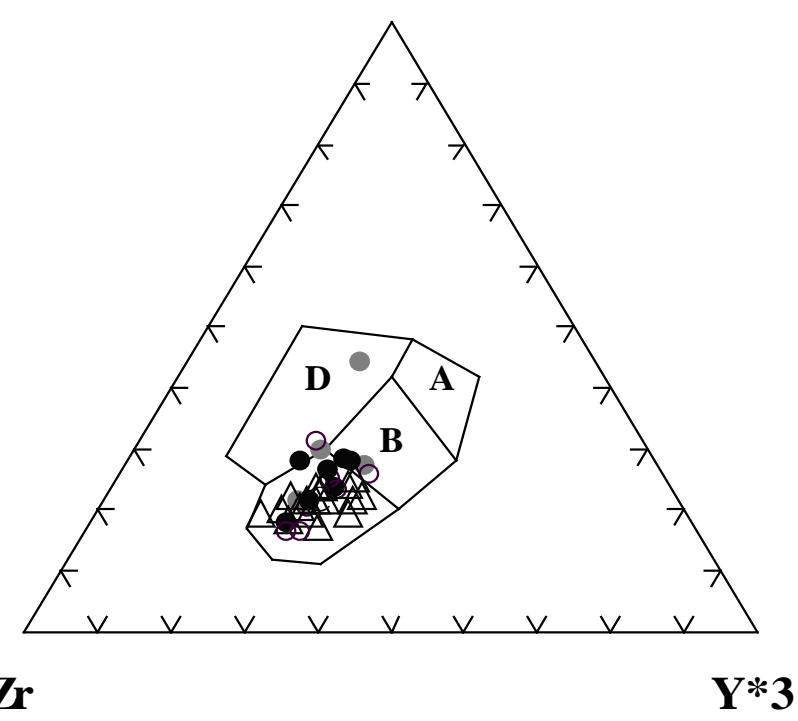

Figure 9. Position of calc-alkaline volcanic rocks of Mako and Foulde groups in the $\mathrm{Ti} / \mathrm{Zr} 100-\mathrm{Y}^{*} 3$ diagram (Pearceet \& Cann, [41]). 


\section{Conclusion}

The three complexes of Mako and Foulde Groups containing calc-alkaline volcanic rocks of Paleoproterozoictype are located from the North to the South of the Kedougou inlier. These complexes are composed of basic, intermediate and acid elements. The rocks show great similarities for major and trace elements, but they have some differences regarding certain lithophilic elements like Sr, Ba, U, Rb and the composition of Cpx. They probably originate from the same magmatic source; however, their development in such different environments as intra-block basins (Mako), marginal basins (Bagnomba) and pull-apart basins (Foulde) has presumably engendered some differences in their composition.

\section{References}

[1] Bassot, J.P. (1966) Etudes géologiques du Sénégal oriental et de ses confins guinéo-maliens. №40, Edition Bureau de Recherches Géologiques et Minières, 321 p.

[2] Abouchami, W., Boher, M., Michard, A. and Albarede, F. (1990) A Major 2.1 Event of Mafic Magmatism in West Africa: An Earlier Stage of Crustal Accretion. Journal of Geophysical Research, 95, 17605-17629. http://dx.doi.org/10.1029/JB095iB11p17605

[3] Sylvester, P.J. and Attoh, K. (1992) Lithostratigraphy and Composition of 2.1 Ga Greenstone Belts of the West African Craton and Their Bearing on Crustal Evolution and the Archeen-Proterozioc Boundary. Journal of Geology, 100, 377-393. http://dx.doi.org/10.1086/629593

[4] Vidal, M. and Alric, G. (1994) The Palaeoproterozoic (Birimian) of Haute-Comoé in the West African Craton, Ivory Coast: A Transtensional Back-Arc Basin. Precambrian Research, 65, 207-229. http://dx.doi.org/10.1016/0301-9268(94)90106-6

[5] Pouclet, A., Vidal, M., Delor, C., Simeo, Y. and Alric, G. (1996) Le volcanisme birimien du nord-est de la Côte d'Ivoire, mise en évidence de deux phases volcanotectoniques distinctes dans l'évolution géodynamique du Paléoprotérozoïque. Bulletin de la Société Géologique de France, 167, 529-541.

[6] Pouclet, A., Doumbia, S. and Vidal, M. (2006) Geodynamic Setting of Birimian Volcanism in Central Ivory Coast (Western Africa) and Its Place in the Paleoproterozoic Evolution of the Man Shield. Bulletin de la Société Géologique de France, 177, 105-121.

[7] Ama Salah, I., Liegois, J.P. and Pouclet, A. (1996) Evolution d’un arc insulaire océanique birimien précoce au Liptako Nigérien (Sirba). Géologie, géochronologie et géochimie. Journal of Africa Earth Sciences, 22, 235-254. http://dx.doi.org/10.1016/0899-5362(96)00016-4

[8] Zonou, S., Karche, J.P., Lapierre, H., Lemoine, S. and Rossy, M. (1985) Volcanismes tholeïtique et ca1co-a1calin dans les formations du Birrimien supérieur de Bouroum (N.E du Bukina Faso). Centre de. Recherches. Académiques et Scientifiques. Paris, 301, Série II, 309-314.

[9] Béziat, D., Bourges, F., Debat, P., Lompo, M., Martin, F. and Tollon, F. (2000) A Paleoproterozoic Ultramafic-Mafic Assembage and Associated Volcanic Rocks of the Boromo Greenstone Belt: Fractionates Originating from Island-Arc Volcanic Activity in the West African Craton. Precambrian Research, 101, 25-47. http://dx.doi.org/10.1016/S0301-9268(99)00085-6

[10] Lahondèrea, D., Thiéblemont, D., Teguey, M., Guerrot, C. and Diabate B. (2002) First Evidence of Early Birimian (2.21 Ga) Volcanic Activity in Upper Guinea: The Volcanics and Associated Rocks of the Niani Suite. Journal of African Earth Sciences, 35, 417-431. http://dx.doi.org/10.1016/S0899-5362(02)00145-8

[11] Bassot, J.P. (1987) Le complexe vo1cano-plutonique ca1co-a1calin de la rivière Daléma (Est Sénégal): Discussion de sa signification géodynamique dans le cadre de l’orogénie Eburnéenne (Protérozoïque Inférieur). Journal of African Earth Sciences, 6, 109-115.

[12] Boher, M., Abouchami, W., Michard, A., Albarede, F. and Arndt, N.T. (1992) Crustal Growth in West Africa at 2.1 Ga. Journal of Geophysical Research, 97, 345-369. http://dx.doi.org/10.1029/91JB01640

[13] Diallo, D.P. (1994) Caractérisation d'une portion de croûte d'âge Protérozoïque inférieur du Craton Ouest Africain: Cas de l'encaissant des granitoïdes dans le Supergroupe de Mako (Boutonnière de Kédougou). Implications géodynamiques. Thèse d'Etat UCAD, $446 \mathrm{p}$.

[14] Dioh, E. (1995) Caractérisation, signification et origine des formations birimiennes encaissantes de granite de Dioumbalou (Partie septentrionale de la boutonnière de Kédougou-Sénégal Oriental). Thèse d’Etat UCAD, 427 p.

[15] Ndiaye, P.M., Dia, A., Vialette, A., Diallo, D.P., Ngom, P.M., Sylla, M. and Wade, S. (1993) Les granitoïdes du Protérozoïde inférieur du supergroupe de Dialé-Daléma. Données pétrographiques, géochimiques et géochronologiques nouvelles. CIFEG, Publication occasionnelle. 23 p, A7-AIl. 
[16] Pawlig, S., Gueye, M., Klischies, R., Schwars, S., Wemmer, K. and Siegesmud, S. (2006) Geochemical and Sr-Nd Isotopic Data on the Birimian of the Kedougou-Kenieba Inlier (Eastern Senegal): Implications on the Palaeoproterozoic Evolution of the West African Craton. Geological Society of South Africa, 17 p.

[17] Ngom, P.M., Gueye, M., Cissokho, S., Jeron, J.L., Treuil, M. and Dabo, M. (2007) Signification géodynamique des roches volcaniques dans les ceintures de roches vertes d’âge paléoprotérozoïque; Exemple de la partie méridionale du Supergroupe de Mako, boutonnière de Kédougou (Sénégal). Approche des éléments en traces. Journal des Sciences et Technologies, 5, 52-71.

[18] Cissokho, S. (2010) Etude Géologique du secteur de Mako (partie méridionale du Supergroupe de Mako, boutonnière de Kédougou-Kéniéba, Sénégal oriental): Implications sur la diversité magmatique. Thèse 3ème cycle, UCAD, 177 p.

[19] Dioh, E., Beziat, D., Gregoire, M. and Debat, P. (2009) Origin of Rare Earth Element Variations in Clinopyroxene from Plutonic and Associated Volcanic Rocks from the Fouldé Basin, Northern Kedougou Inlier, Sénégal, West Africa. European Journal of Mineralogy, 21, 1029-1043. http://dx.doi.org/10.1127/0935-1221/2009/0021-1963

[20] Ngom, P.M. (1995) Caractérisation de la croûte birimienne dans les parties centrale et méridionale du Supergroupe de Mako. Implications géodynamiques et pétrogénétiques. Thèse d'Etat UCAD, 240 p.

[21] Moussolo, J.B. (2000) Etude du volcanisme de Baniomba dans la partie méridionale du Supergroupe de Mako: boutonnière de Kédougou-Kéniéba (Sénégal oriental). Mémoire de DEA Université Cheikh Anta Diop, 74 p.

[22] Theveniaut, H., Ndiaye, P.M., Buscail, F., Coueffe, R., Delor, C., Fullgraf, T. and Goujou, J.C. (2010) Notice explicative de la carte géologique du Sénégal oriental à 1/500 000. Ministère des Mines, de l'Industrie, de l'Agro-Industrie et des PME, Direction des Mines et de la Géologie, Dakar, 120 p.

[23] Bassot, J.P. and Dommanget, A. (1986) Mise en évidence d’un accident majeur affectant le Protérozoïque inférieur des confins Sénégalo-Maliens. Comptes Rendus de l'Académie des Sciences, 302, Série II, 1101-1106.

[24] Dioh, E. (1986) Étude des roches magmatiques birrimiennes de la région de Sonfara-Laminia-Médina Foulbé (Sénégal oriental). Thèse 3ème cycle. Université Nancy I, 144 p.

[25] Diallo, D.P. (2001) Le paléovolcanisme de la bordure occidentale de la boutonnière de Kédougou, Paléoprotérozoïque du Sénégal oriental: incidences géotectoniques. Journal of African Earth Sciences, 32, 919-940. http://dx.doi.org/10.1016/S0899-5362(02)00063-5

[26] Ndiaye, P.M. (1994) Evolution au Protérozoïque inférieur de la région Est-Saraya (craton de l’Afrique de l’Ouest, Sénégal-Mali). Tourmalinisations, altérations hydrothermales et minéralisations associées. Thèse d’Etat UCAD, 372 p.

[27] Calvez, J.Y., Feybesse, J.L., Ledru, P. and Milesi, J.P. (1990) Géochronologie du Protérozoïque inférieur du craton ouest africain (méthode d’évaporation directe de zircons isolés). 13eme réunion des Sciences de la Terre, Grenoble, France, 26.

[28] Hirdes, W. and Davis, D.W. (2002) U-Pb Geochronology of Paleoproterozoic Rocks in the Southern Part of the Kedougou-Kenieba Inlier, Senegal, West Africa: Evidence of Diachronous Accretionnary Development of the Ebur- nean Province. Precambrian Research, 118, 83-99. http://dx.doi.org/10.1016/s0301-9268(02)00080-3

[29] Gueye, M., Ngom, P.M., Diène, M., Thiam, Y., Siegesmund, S., Wemmer, K. and Pawlig, S. (2008) Intrusive Rocks and Tectono-Metamorphic Evolution of the Mako Paleoproterozoic Belt (Eastern Senegal, West Africa). Journal of African Earth Sciences, 50, 88-110. http://dx.doi.org/10.1016/j.jafrearsci.2007.09.013

[30] Dioh, E., Beziat, D., Debat, P., Gregoire, M. and Ngom, P.M. (2006) Diversity of Paleoproterozoic Granitoids of the Kedougou Inlier (Eastern Senegal): Petrographical and Geochemical Constraints. Journal of African Earth Sciences, 44, 351-371. http://dx.doi.org/10.1016/j.jafrearsci.2005.11.024

[31] Dia, A., Van Schmus, W.R. and Kroner, A. (1997) Isotopic Constraints on the Age and Formation of a Paleoproterozoic Volcanic Arc Complex in the Kedougou Inlier, Eastern Senegal, West Africa. Journal of African Earth Sciences, 24, 197-213. http://dx.doi.org/10.1016/S0899-5362(97)00038-9

[32] Morimoto, N., Fabries, J., Ferguson, A.K., Ginsburg, L.V., Ross, M., Seifert, F.A., Zussman, J., Aoki, K. and Gottardi, G. (1988) Nomenclature of Pyroxenes (Subcommitee on Pyroxene, IMA.). Mineralogical Magazine, 52, 535-550.

[33] Leterrier, J., Maury, R.C., Thonon, P., Girard, D. and Marchal, M. (1982) Clinopyroxene Composition as a Method of Identification of the Magmatic Affinities of Paleovolcanic Series. Earth and Planetary Science Letter, 59, 139-154. http://dx.doi.org/10.1016/0012-821X(82)90122-4

[34] Gelinas, L. and Brooks, C. (1974) Archean Quench-Texture Tholeiites. Canadian Journal of Earth Sciences, 11, 324340. http://dx.doi.org/10.1139/e74-028

[35] Sato, H. (1977) Nickel Content of Basic Magma: Identification of Primary Magmas Measure of the Degree of Olivine Fractionation. Lithos, 10, 113-120. http://dx.doi.org/10.1016/0024-4937(77)90037-8

[36] Hart, S.R. and Davis, K.E. (1978) Nickel Partitioning between Olivine and Silicate Melt. Earth and Planetary Science Letters, 4, 203-219. http://dx.doi.org/10.1016/0012-821X(78)90091-2 
[37] Diene, M. (2012) Evolution structural d’un segment du Craton Ouest Africain: Cas des formations paléoprotérozoïques du Supergroupe de Mako, Boutonnière de Kédougou-Kéniéba (Sud-Est du Sénégal). Thèse de Doctorat unique UCAD, $153 \mathrm{p}$.

[38] Diene, M., Gueye, M., Diallo, D.P. and Dia, A. (2012) Structural Evolution of a Precambrian Segment: Example of the Paleoproterozoic Formations of the Mako Belt (Eastern Senegal, West Africa). International Journal of Geosciences, 3, 153-165. http://dx.doi.org/10.4236/ijg.2012.31017

[39] El Hadi, H., Tahiri, A., Cabrera, F.S., Lodeiro, F.G., Perez, A.A. and Martinez Poyatos, D.J. (2006) Un exemple de volcanisme calco-alcalin de type orogénique mis en place en contexte de rifting (Cambrien de l'oued Rhebar, Meseta occidentale, Maroc). Comptes Rendus Geoscience, 338, 229-236. http://dx.doi.org/10.1016/j.crte.2005.12.006

[40] Leat, P.T., Thompson, R.N., Morisson, M.A., Henry, G.L. and Dickin, A.P. (1988) Compositionnally Diverse Miocene Recent Rift-Related Magmatism in Northwest Colorodo Partial Melting and Mixing of Mafic Magma from Three Different Asthenospheric Mantle Sources. In: Cox, X., Menzi, Y., et al., Eds., Oceanic and Continental Lithosphere: Similarities and Difference, Journal of Petrology (Special Issue), 351-357.

[41] Pearce, J.A. and Cann, J.R. (1973) Tectonic Setting of Basic Volcanic Rocks Determined Using Trace Elements Analyses. Earth and Planetary Science Letters, 19, 290-300. http://dx.doi.org/10.1016/0012-821X(73)90129-5 